\title{
The Bible in Afrikaans: A direct translation - A new type of church Bible
}

\author{
Author: \\ Christo H.J. van der Merwe ${ }^{1}$ \\ Affiliation: \\ ${ }^{1}$ Department of Ancient \\ Studies, University of \\ Stellenbosch, South Africa \\ Correspondence to: \\ Christo van der Merwe \\ Email: \\ cvdm@sun.ac.za \\ Postal Address: \\ 17 Woltemade Street, Die \\ Boord, Stellenbosch 7600, \\ South Africa \\ Dates: \\ Received: 19 Dec. 2011 \\ Accepted: 31 Mar. 2012 \\ Published: 24 July 2012 \\ How to cite this article: \\ Van der Merwe, C.H.J., 2012 , \\ 'The Bible in Afrikaans: \\ A direct translation - $A$ \\ new type of church Bible', \\ HTS Teologiese Studies/ \\ Theological Studies 68(1), \\ Art. \#1204, 8 pages. http:// \\ dx.doi.org/10.4102/hts. \\ v68i1.1204
}

(C) 2012. The Authors.

Licensee: AOSIS

OpenJournals. This work

is licensed under the

Creative Commons

Attribution License.
Translating the Bible so that target audiences can easily understand the meaning of the text has dominated the theory and practice of Bible translation since the 1960s. Source oriented translations that are typically associated with word-for-word translations received little theoretical reflection. However, developments in Translation Studies have made it clear that the latter type of translations do not provide the type of equivalence more conservative churches really call for. The story of the Bible in Afrikaans relates to how the Bible Society of South Africa (BSSA) has taken seriously the needs of churches in South Africa for a sourceoriented translation and teamed up with scholars to develop an academically justifiable model for a new type of church Bible. The functionalist model of Christiane Nord (1997) was used as point of departure and complimented by that of Ernst-August Gutt (2000). Pointing out the accomplishments and challenges of this pioneering project, this article paves the way for a scholarly discourse on source-oriented translations of the Bible.

\section{Introduction}

For many years the dichotomy of formal versus functional equivalence has typically been used to distinguish between alternative types of Bible translations. In recent years, not only have advances in Translation Studies, but also a lively interest in the history of Bible translations, contributed to a more sophisticated portrayal of the types of Bible translations that have been made through the ages. It is now widely accepted that the various Bible translations should rather be positioned on a continuum ranging from source language to target-language-oriented translations. ${ }^{1}$ Word-for-word translations dominated the world of Bible translations for centuries, since the 1970s - and until the first few years of this century - target-oriented translations have tended to dominate the landscape of Bible translation (Carson 1993:37-67). The perception that translations of the Bible for people to readily understand could be made in terms of 'scientific' principles - was certainly a major catalyst in this regards. This lofty ideal has inspired translation agencies and publishing houses to prepare Bible translations which people in general could read and understand. However, one of the downsides of this enterprise is that relatively little attention has been paid to the needs of established churches to have updated versions of their word-forword translation that are more source language and culture oriented. In other words, it is the need for translations, the primary goal of which is not to communicate in terms of the language and conceptual world of the modern target audience, but for translations that can function in the liturgy and environment where the strangeness of culture and difficulties of the ancient text are acknowledged. The dilemma facing translators who are commissioned to prepare more sourcelanguage-oriented translations of the Bible is that there is no way to academically justify the old notion of formal equivalence.

The aim of this article is to contribute to the academic discourse in this regard. In other words, how can the needs of established churches for a source-language-oriented translation of the Bible be met in an academically justified way? The story of 'The Bible in Afrikaans: A direct translation', will be used to illustrate a possible way to meet this new challenge. According to Prof. T. Hermans (pers. comm., 08 September 2009), literary novels translated into English are often perceived as 'direct translations' - the same technical sense of how the word is used in this article. Since the main hypothesis of this article is that the 'new type of Church Bible' would strive to be a 'direct translation', the story of the Bible in Afrikaans may also be relevant to translators of literary works. At the outset, it should be pointed out that this story provides the perspective of a scholar who primarily specialises in Biblical Hebrew linguistics. He became interested in Bible translation and Translation Studies in his capacity as member of the Centre for Bible Interpretation and Translation in Africa (CEBITA) and its attempts to serve Bible translation in Africa academically.

Since the project is part of a series of translation acts imbedded in the history of Afrikaans, its speakers and their churches, I will commence with a brief description of the language and its 1.Cf. also Pym (2010:6-42) 
speakers. ${ }^{2}$ Secondly, a brief overview of the history of the translation of the Bible into Afrikaans will be provided. Thirdly, special attention will be paid to the run-up and development of this project, in which the willingness of the Bible Society of South Africa (BSSA) to listen and to serve, as well as to partner with academic institutions, has played a pivotal role. In this section, the model that was developed in negotiation with the churches will also be described. Fourthly, how the process to apply the model has unfolded, and the challenges that emerged during the initial stages of this ambitious project with more than 120 co-workers, will be discussed. In conclusion, some of the findings as well as remaining challenges of this project will be pointed out.

\section{The Afrikaans language and its speakers}

Afrikaans is one of the 11 official languages of South Africa. It is the mother tongue of about six million South Africans, whilst it is estimated that between 15 and 20 million people in South Africa and Namibia can speak the language. Although it borrowed from Malay, French, Bantu and Khoisan languages, Afrikaans is a West Germanic language. About $90 \%$ of its vocabulary has Dutch origin. Afrikaans is a relatively young language and is spoken by mainly White and Coloured South Africans (see also http://en.wikipedia. org/wiki/Afrikaans).

\section{Translations of the Bible into Afrikaans}

After some attempts in the late 19th century to translate the Bible into Afrikaans, the first translation of the entire Bible was published in 1933.

Since most readers at that stage were used to the Dutch Statenvertaling, it was attempted to stay as close as possible to this older word-for-word translation. The translation was well received. A revision was published in 1953. As part of the meaning-based wave of translations that has swept across the world since the 1970s, speakers of Afrikaans received their version in $1983 .{ }^{3}$ As a project driven by the three major White Reformed churches, this Bible was presented to Afrikaans readers as the new 'official' church Bible. Although it was at first - as is typical with cases of new 'official' translations - fiercely criticised from various angles, it has gained more acceptance during the last decade as people got used to it.

A number of conservative evangelical churches, as well as the Roman Catholic Church, however, never accepted this Bible.

\section{The quest for a new translation: $A$ new model}

In the 1990s a significant number of churches expressed the need for a translation that was 'closer' to the source texts

2.For useful overviews of 'action theory' see, Snell-Hornby (2006) and Pym (2010 $50-52)$

3.For an overview of the translation of the Bible into Afrikaans, cf. Nienaber and Heyl (n.d.), Weiss (1990) and Hermanson (2002). than the 1983 functional equivalent translation. The Catholics and Anglicans, on the one hand, wanted a translation with a more formal register, whilst conservative evangelicals on the other, wanted a translation which they believed would be more suitable for serious readers and Bible study groups. ${ }^{4}$

In South Africa the BSSA meets each October or November with representatives of all the churches in Southern Africa that use translations of the Bible in Afrikaans (CBA). A request by some of the Reformed churches for a revision and/or new concordant translation in Afrikaans was put on the agenda of this meeting in the mid-1990s. Since the BSSA at that stage had just heeded a request for an Afrikaans Bible for deaf people, the latter agenda item was not immediately tended to, but carried over for a number of years.

CEBITA was established by Prof. F.E. Deist in 1996 at the University of Stellenbosch and the mission of the Centre was to serve Bible translation in Africa, academically (see also http:/ / www.cebita.org). The Centre reacted on this agenda item by launching a project that investigated the implications and academic justification of the quest for 'a concordant translation'. The findings of this project were summarised in Van der Merwe (1999) as follows:

An Afrikaans concordant translation in the sense of a word for word translation of the source language cannot be justified. A broadening of what is understood by the term 'concordant' is necessary so that it also includes semantic, text-linguistic, pragmatic and socio-linguistic agreement. If the inference model of communication is used (in contrast to the code model of the functional equivalent method), it implies that the reader will not be able to understand the translated text without being provided with ample historic and cultural historic explanatory notes. This implies that the translation will be a very bulky document. The electronic media and internet [sic], however, presents $[s i c]$ various possibilities for making such a translation more accessible and cost-effective for the relatively small group of target readers. (pp. 293-306)

Since a mere revision of the word-for-word 1933/1953 version, or a new formal equivalent translation could not be justified in terms of the developments in Translation Studies, the challenge was to find a new model that would (1) be practical and (2) lead to a translation that would be acceptable to the churches.

As a first step to meet this challenge, the BSSA requested CEBITA to assist them in drawing up the agenda for a conference in August 2001 covering recent developments in Translation Studies, Bible Translation, Greek and Hebrew linguistics - as well as the development of the Afrikaans language, which needed to be considered if a new major translation of the Bible in Afrikaans was to be made. The papers read at this highly successful conference were published in 2002. ${ }^{5}$ As a follow-up on this conference, the CBA asked 4.See the minutes of The Committee for the Bible in Afrikaans from 1995 to 2000 .

5.Cf. Naudé and van der Merwe (2002). The following papers were read: A brief overview of Bible translation in South Africa (E.A. Hermanson): Problems in the overview of Bible translation in the theoretical foundation of the functionalca (Evalent approach (G.J.C. Jordaan); No culture shock? Addressing the Achilles heel of modern Bible translations (S.J. Joubert); An overview of recent developments in translation studies with special reference to the implications for Bible translation (J.A. Naudé); Corpus-based translation research: its developments and implications for general, literary and Bible translation (A. Kruger); Translation as secondary communication. The relevance theory perspective of Ernst-August Gutt (K. Smith); Some considerations 
scholars from four major Afrikaans- speaking universities to prepare four types of translations from a selection of passages in the Bible (Ex 33; Ps 16; Is 1; Mt 5:1-20; Rm 7:7-26; Rv 7). The idea was that the dynamics of such a process would lead to academically well-founded sample translations that could be submitted to the churches to help them determine what exactly they wanted. The types of translations which were requested were the following:

- A version that is highly concordant and source-language oriented, and that maintains the source language idiom.

- A version that represents a crystal-clear translation, in a natural and simple style, that is suitable and attractive as a reading Bible for the broadest possible public of Afrikaans-speaking people.

- A version aimed to be read in church (i.e. for liturgical purposes), but which could also be used in catechism and Bible study - with special attention to the literary quality of the translation.

- A revision of the 1983 translation.

At the University of Stellenbosch, CEBITA was commissioned to take responsibility for this project. It was immediately realised that these 'translation briefs' primarily represented perceptions of various types of Bible translations Bible readers may have a need for. They were not formulated in terms of a justifiable theoretical frame of reference. ${ }^{6}$ It was decided to launch a project that would provide the above-mentioned four needs with a solid academic basis. For these purposes, firstly, the insights gained from the 2001 conference were taken seriously, and secondly, a multi-disciplinary approach was assumed drawing on the expertise of all available scholars in the Western Cape. ${ }^{7}$ The findings of this project and its implications for a new Bible translation in Afrikaans were submitted to the CBA in November 2002. ${ }^{8}$ As far as the theoretical frame of reference is concerned, the following were the most significant recommendations:

- That the functionalistic model of Nord (1997) should be followed and that, from the beginning, close and extensive

\footnotetext{
(Footnote 5 continues...)

on Bible translation as complex process (J.G. van der Watt \& Y. Kruger); A new framework for Bible translation (T. Wilt); Towards a 'literary' translation of the Scripture: with special reference to a 'poetic' rendition (E.R. Wendland); Bible translation in Africa. What implications does the new UBS perspective have fo Africa? An overview in the light of the emerging new UBS translation initiative (A.O. Mojola); Functional equivalence and the new Dutch translation project (K.F. de Mojola); Functional equivalence and the new Dutch translation project (K.F. de Blois \& T. Mewe); An overview of recent developments in the description of Biblical Hebrew relevant to Bible translation (C.H.J. van der Merwe); What happens when meaning, interpretation and literary theory (H. de Plooy); The language ecology of a new Afrikaans Bible (F. Ponelis).
}

6.At that stage, some scholars who joined CEBITA had been focusing for many years on a more adequate linguistic description of Biblical Hebrew as well as any insights from modern linguistics that could be used. For these purposes, insights from Relevance Theory (e.g. Blakemore 1987, 2001; Blass 1990; Sperber \& Wilson 1986) had proven to be useful, in particular for the understanding of discourse particle (cf. Van der Merwe 1993a, 1993b). Gutt, whose ground-breaking works (1991 and 2000) had been widely critised (e.g. Wendland 1996) was, however, appreciated in Stellenbosch (cf. Van der Merwe \& Winkler 1993, 1994). A doctoral project on some of the implications from Gutt's insights were completed in 2001 (cf. Smith 2001) Since then, other projects were launched in which Gutt's views were critically used (see for example, Chemorion 2008).

7.Prof. Ilse Feinauer, a translation studies scholar at the University of Stellenbosch played a pivotal role in introducing the CEBITA team to the views of Christiane Nord.

8.For full details of this project, as well as its recommendations, cf. Van der Merwe and Basson (2003). attention should be paid to the 'brief' for the translating team of each type of translation. ${ }^{9}$

- That Gutt's (2000:136) distinction between direct and indirect translation should be accepted as a thoroughly justified theoretical framework for both a more solemn Bible and for a Bible that is easy to read.

Nord's model was embraced for various reasons: Firstly, it was regarded to be descriptively adequate. In other words, it was based on close analyses of a wide range of empirical realities that have an influence on translation processes. Since the model was developed in an academic environment where professional translators were trained, its strengths resided, amongst other things, in the parameters it established for a translation to be successful. In contrast to earlier prescriptive models that focused primarily on ways to establish equivalence between the source and target text, Nord's model provides a much wider scope of the factors involved in a translational act. ${ }^{10}$

Secondly, Nord acknowledges that any translation should primarily be evaluated in terms of the function it is supposed to fulfil. The nature of this function, however, is typically the result of a negotiation process between the commissioner of a translation and a professional translator. For our Bible translation project, it implied that a range of issues should be agreed upon between the churches - that the BSSA served as commissioner - and the team of scholars (appointed by the BSSA in consultation with the churches) which were entrusted with carrying out the translation project. These included, for example, the 'exact' function of the translation ('Skopus'), the target users, the translators (and their academic abilities), the source texts that would be used, details of what the product should look like and the processes that were envisaged in the translation process. For Bible translation consultants, ${ }^{11}$ most of these parameters are nothing new as far as planning a new translation project is concerned. Nord's model, in a sense, confirmed the significance of each of these parameters and provided additional academic rigor to the entire process. Furthermore, it underscored the pivotal role of the 'translation brief' and, in particular, the value of a clearly defined 'Skopus' as a practical guiding principle.

Thirdly, although fully acknowledging the basic tenets of a functionalist approach to translation, Nord's model accommodates the high value Bible translators place on the source text of the Bible. According to Nord, a distinction must be made between an 'instrumental' (1997:51) and 'documentary' translation (1997:47-51). In the translation of a commercial advertisement the source text is irrelevant, as long as the advertisement in the target text 'works'. However,

9.Working independently of their colleagues at the University of Stellenbosch, the team from the University of the Free State, headed by Prof. J.A. Naudé, also strongly recommended that the functionalist model of Nord had to be implemented.

10.Nord's model forms part of what is regarded as the 'cultural turn' in Translations Studies. This in turn refers to a paradigm shift away from prescriptive attempts to find guidelines to establish equivalence at various linguistic levels between a
source and a target text (e.g. Nida \& Taber 1969; see also Munday 2001) towards descriptive oriented investigations into all the culture-embedded translational acts involved in the process of translation (see Snell-Hornsby 2006). According to Prof. involved in the process of translation (see Snell-Hornsby 2006). According to Prof.
E.R. Wendland (Email 18 September 2011) this cultural turn already took place in



11. With 'translation consultant' I refer to translation officers of the UBS who typically manage and guide from 4 to 12 translation projects. 
in the translation of a documentary text, like a legal document or the Bible, the relation between the target and source text is typically of fundamental importance.

Fourthly, Nord's concept of 'loyalty' defines the role of the translator in the negotiation process (Nord 1997:123-125). According to Nord (pers. comm., 18 May 2011), in a documentary translation, the translator always has a multiple loyalty: towards the commissioner and towards the author(s) of the source text. On the one hand, the translator is obliged to service the needs of the commissioner; on the other, the translator must be loyal to what the author of the source text wants to communicate. When a commissioner wants to accomplish a function $x$ with the translated text, the translator must point out under what conditions such a function for the translated text would be possible, and/or how the author of the source text's intent could be compromised by the specific requirements of the commissioner. For our project it meant: that when the CBA wanted a concordant translation (Version 1 above), the team of scholars appointed by the BSSA had to point out the implications of their request, for example, the target text would often be stylistically strange; the target text would often be difficult to understand for readers. If the CBA would be happy with the strange style of the target text, but placed a premium on understanding the text, the target text would need to be supplemented by footnotes and marginal notes.

Fifthly, Nord's notion of 'subjective theories' confirms the fact that Bible translators must take seriously the ecclesiastic traditions, ideologies and perceptions concerning the Biblical text and its interpretation (Nord 2001:192-193). This means that translators may sometimes need to sacrifice a scholarly, superior translation for acceptability. This happens, of course, within certain limits. Some examples in these regards are the translation of the name of God; the use of capital letters in Old Testament passages which could be interpreted as referring to Jesus; et cetera.

Since the essence of the recommendations of the abovementioned project by CEBITA that were inspired by Nord were echoed by the project conducted at the University of the Free State (where Nord is a visiting professor), the CBA asked representatives of the four universities (Universities of Stellenbosch, Free State, Pretoria and North West) to cooperate and prepare two versions in terms of Nord's model, viz., one similar to version two, which we will call the 'Easy-to-read Bible', and one similar to version three, above; the latter, we will call the 'Church Bible'. For each version a translation brief had to be prepared in terms of Nord's frame of reference. However, for these purposes, Nord's frame of reference was required to be supplemented by Gutt's (2000) insights. Why this was necessary, is explained in the next two paragraphs.

Although it could be argued that the translation brief of the 'Easy-to-read Bible' could be formulated in terms of Nord's model with relative ease, this was not the case with the 'Church Bible'. The problem with Nord's model in this regard was that it had been conceptualised in an academic setting where translators were taught to resolve translation problems typically in the main body of the target text. And, the main body of the text 'alone' had to fulfil the required communicative act. Of course, this view accorded well with the fact that typical readers of printed material tend to regard footnotes as a second text. However, it could also be argued that this is merely a convention associated with book technology and that hypertext technology was already beginning to change this. Furthermore, the necessity of providing additional information to the translation of the Bible had been realised by some of the earliest English and Dutch Bible translators. De Vries (2003) describes the role of the marginal notes in the Statenvertaling of 1644 as follows:

It is clear that the nota marginalia were crucial to balance the perspicuitas and the word-by-word inspiration and that text and paratext together ensured that this translation could perform the religious functions the Reformed leaders and communities in the Netherlands demanded. (pp. 173-193)

However, he also points out:

When in the 19th and 20th century Bible Societies replaced Synods as commissioners of translations, this change in institutional context showed itself most clearly in the quantity and quality of paratextual elements. To prevent theological and political problems, the amount of paratext was sharply reduced and the remaining paratext was strictly factual and neutral. (pp. 173-193)

The removal of this additional information could - according to Prof. J.A. Naudé (pers. comm., 16 October 2010) - be traced to attempts at the end of the 19th century to produce translations that did not look like translations (which additional information would betray). It could also be argued that the drive by translation agencies - in order to produce affordable Bibles - contributed to a widely held current perception that a Bible is not supposed to have notes, or at least as few as possible. The moment a significant number of additional information is added to a Bible translation, it loses its status as the Bible, and becomes a 'Study Bible'. However, the question whether the supplementary information is crucial for understanding the translation, seldom comes into play.

Nord is fully aware of the necessity of supplementary information if the translation of an ancient text like the Bible would like to communicate effectively to modern target text readers. The 'Skopus' of Berger and Nord (1999), a translation of the New Testament, is called 'Otherness Understood' (see also Nord 2002:98-116). Since her model implies that the bridge of the otherness of the culture of the source language needs to be crossed inside the text, it implies a 'longer' translated text. This is indeed the case with Berger and Nord (1999). In accordance with Nord's notion of 'subjective theories,'12 it was argued that in our case, conservative readers who are used to the 1933/1953 wordfor-word translation would be alienated by 'additions' to the 12.See Van der Merwe and Basson (2003:555). 
Bible translation that they were accustomed to. This would in particular be the case if translators would concede that the additions were not to be found 'literally' in the source text.

As we have mentioned above, Nord's model implies a negotiation process in which the translator must spell out the implications of their requirements to the commissioner (in this case the churches). In this project, we therefore assumed that her model could accommodate a negotiated product which might look different from current conventions in the world of secular translations, but which did accord with her notions of loyalty towards both the commissioner of the translation and the author(s) of the source text.

Why did Gutt (2000) - whose relevance-theoretical approach to Bible translation has been criticised as being unpractical - appeal to us? I think the most important reason is that we appreciate Gutt for what he is trying to do. Namely, he tries to provide an explanatory model for Bible translation. In other words, he does not try to provide an account of Bible translation that is based on the observation, description, analyses and systematisation of all the processes that are involved, and all the parameters that should be considered in the process of Bible translation (Gutt 2000:204-206). He does not by any means try to provide a new way or method of Bible translation. Rather, his aim is to explain that translation is a mode of secondary communication and then, in the light of this explanation, to point out the implications of his theory for the translation of an ancient text like the Bible. He, for example, points out that Bible translation is a difficult form of secondary communication. ${ }^{13}$ In other words, the chances that the target text could easily be misunderstood are very great. As a mode of communication, translators must consider the fact that the semantics of individual utterances are typically underspecified. It is only in the context of use that the relevant dimension of an utterance's semantic potential is profiled. By 'context' is not meant only the co-text, but also the conceptual worlds of both interlocutors. If interlocutors make wrong assumptions about the conceptual worlds of each other - even when they speak the same language at the same time and place - communication tends to be impeded. If this is the case when interlocutors share the same code (i.e. language) at the same time and place, it is obvious why successful communication by means of a translation of an ancient (limited) corpus-based language provides a huge challenge. It may even be argued that since this language is that of an ancient far-off culture, which is based on texts of which the transmission was long and complicated, successful communication sometimes is nearly an impossible task. Gutt's assessment of Bible translation as an extreme form of secondary communication does not represent for Bible translators (or Translation Studies scholars like Nord) something that they were not aware of. It rather confirms and explains the hard realities Bible translators must face.

13.These realities of Bible translation are formulated from a similar perspective in terms of the various 'frames' that are involved in Bible translation by Wilt and Wendland (2008). See also Wilt (2002b). Although Gutt's model of communication i.e. Relevance Theory, was conceptualised to supplement generative approaches to language, Evans and Green (2006:459-465) illustrate how this approach resonates in various aspects well with a recent insights in Cognitive Linguistics of how language and communication works.
Gutt (2000) does not try to provide any strategy to face these challenges. He rather again tries to explain the types of strategies that Bible translators typically follow, and how these strategies impact their attempts to communicate what the source-language authors tried to say. According to Gutt (2000:35-46), translation is an interpretative use of language; in other words, a translator tries to produce a target text that interpretatively resembles the source text. ${ }^{14}$ This means that a translator strives toward reproducing the communicative clues in the source text. Although he does not define the concept very clearly, Gutt uses the term 'communicative clues' to refer to all those linguistic phenomena that a speaker or author uses to guide hearers or readers toward understanding what he or she tries to communicate (2000:132-167).

Although Gutt does not state it in these terms, what a translated target text ultimately looks like, depends on the function it is supposed to fulfil. When the CBA said 'create a crystal-clear translation, in a natural and simple style, that is suitable and attractive as a Reading Bible for the broadest possible public of Afrikaans-speaking people', such a translation would aim to interpretively resemble the source text and to account for all the communicative clues identifiable in the source texts. However, in order to make the target text 'suitable and attractive' for a modern audience, the CBA had to concede that the target text must be moulded in terms of the conceptual world and preferences of the broadest possible public'. What the translators were required to offer was their interpretation of the source text that would make sense to the target audience. Gutt (2000:132-136) likens this type of a translation to 'indirect speech', it is when $x$ reports: ' $y$ said that ...' The addressee knows that $y$ is not quoted verbatim, but that $x$ interprets what $y$ said. When, for example, my wife asks me to tell her what a preacher just said over the radio (when she was not present), we both know that I convey to her my interpretation of what the preacher said. If my Grade 7 son asks me this question too, I would try to report again as faithfully as possible what the preacher said. This time, however, the report would most probably be formulated differently to accommodate a Grade 7 boy's conceptual world. In terms of Gutt's metaphor, the notion 'indirect translation' includes all those types of translations in which one or other type of compromise is made in the translated text itself to accommodate the linguistic preferences and conceptual world of a modern target-language audience.

In contrast, a direct translation strives to interpretively resemble the source text by producing all the communicative clues of the source text in the context envisaged for the original audience, without making any compromises as far as the conceptual world of the target-text audience is concerned. ${ }^{15}$ It is like trying to directly quote Ruth speaking Afrikaans in her day. Gutt (2000:234) fully acknowledges the myriad of practical near impossibilities of this theoretical ideal;

14.In terms of this definition, Nord's instrumental translations (1997:50-52) are not regarded as translations.

15.Although Gutt in recent years further developed some of his views, and also prefered not to use the terms 'direct' and 'indirect' any more, we find the metaphor still useful. For Gutt's more recent works, see http://homepage.ntlworld.com/ ernst-august.gutt/ 
however, these practical realities do not render positing the theoretical ideal invalid.

In October 2003, the CBA indicated they wanted what we called a 'Church Bible', and that the notion of 'direct translation' as formulated above, appealed to them. CEBITA, in cooperation with Prof. J.A. Naudé of the University of the Free State, was asked to prepare a detailed translation brief and Scopus for the new translation. In March 2004 this translation brief was considered, refined and finalised at a meeting of the CBA in Kempton Park. At the heart of this translation brief was the purpose of the new translation, viz. which reads as follows:

Create a clearly understandable; source text oriented Afrikaans translation of the Bible that is suitable for reading and use in church services, as well as catechism, Bible study and personal use. $^{16}$

A feature of the procedures described already in the translation brief, is that exegetes and source-language experts would be responsible for the preparation of a richly annotated word-for-word translation, which the professional translators - who typically do not know the source language - would be required to use for their preparation of the direct translation of the Bible into Afrikaans. This was in contrast to the 1933/1953 and 1983 translation, where exegetes prepared the translation and then scholars of the Afrikaans language and literature 'edited' the translation.

\section{Applying the new model}

In November 2004, Prof. B. Combrink, New Testament scholar and former dean of the Faculty of Theology at the University of Stellenbosch, was appointed by the BSSA, on recommendation of the $\mathrm{CBA}$, as manager of the project. $\mathrm{He}$ would be assisted by an executive committee comprised of exegetes, source-language experts, translation studies experts as well as specialists in the field of the Afrikaans language and literature. Combrink and his team were commissioned, amongst other things, (1) to appoint translation teams for each book $^{17}(2)$ establish the procedures to be followed by the teams (3) prepare a detailed handbook in which these procedures were spelled out, a detailed version of the translation brief, as well as a range of guidelines as far as translation and stylistic choices are concerned, were provided (4) organise training sessions for all the participants (5) evaluate, on the basis of their translation of one chapter of their assigned book, the abilities of each book team to deliver an Afrikaans translation according to the Scopus of the project ${ }^{18}$ and (6) monitor and manage the project in terms of the translation brief.

From the inception of this project it was for both the BSSA and the executive team crystal clear that this was a very

16.'Skep " $\mathrm{n}$ goed verstaanbare, bronteksgeoriënteerde Afrikaanse vertaling van die Bybel wat geskik is vir voorlesing en gebruik in eredienste, asook vir kategese, Bybelstudie en persoonlike gebruik.' http://www.nuwekerkbybel.co.za/index. php?option $=$ com_content \&view $=$ article $\&$ id $=58 \&$ Itemid $=66$

17.For this purpose, all the denominations represented at the CBA were invited to nominate scholars to participate in the project. An unexpressed principle was that the project should be as inclusive as possible concerning denomination, race and sex. This was an ideological and not a practical decision.

18.Most of the preparatory phases were conducted in 2005 and 2006. ambitious project. ${ }^{19}$ On the one hand, part of the theoretical model rested on theoretical insights that were not yet applied on a large scale in a Bible translation project. On the other, an impractically huge team of primarily part-time co-workers, who were spread all over Southern Africa, had to be trained, organised and monitored with an initially very small budget (about $\$ 1.5$ million).

By the beginning of 2007, each book team - which consisted of two exegetes, a source-language expert, a professional translator, an Afrikaans linguist and a literary scholar were supposed to have submitted a chapter of the book they were translating for evaluation by the executive team. ${ }^{20}$ However, it turned out that many teams did not keep to the deadlines, some of them did not understand and/or keep to the translation brief and the quality of the work rendered by others were not of a very good standard. In January 2008, a task team of the executive met to reconsider the organisational set-up of the project.

The most pertinent decisions made include the following, (1) the role of the second exegete in each book team would be suspended since the source-language experts could act as moderators of the first exegete's work (2) the role of the exegetical coordinators would be suspended since the academic ethos amongst scholars made it difficult for one scholar to manage the efforts of the other (3) book teams of the Old Testament, New Testament and Deuterocanonical books would submit their work to editorial committees of these three larger corpora, and the editorial committees would preferably not interact with the book teams and (4) an official of the BSSA would monitor the progress of the various book teams, and interact with them as needed.

Each editorial committee now consists of the project manager, two exegetes, a source language expert, a translation studies scholar, an expert of the Afrikaans language as well two experts of Afrikaans literature. In contrast to the initial (mainly monitoring) role of the executive committee, the editorial committee closely scrutinises the submitted translation of each book team. This means editing it for consistency, refining and even reworking where necessary. The editorial committee meets three to four times a year in sessions of five days. Before each meeting, each member, starting with the source-language expert, scrutinises the translated text that was submitted by the book teams in terms of his or her field of expertise, as well as the translation brief. The exegete and literary scholar eventually consider all the comments, process them, and the 'final text' is sent back to each member. The final text is again read by each member, and his or her comments on this version are discussed at the full sessions. At each of these sessions it is attempted to cover chunks of text comprising about 15 000-20 000 words. These translations are then sent to readers from the churches

19.Since the only project that closely resembles this one (only with a much bigger budget), was that of the new Dutch translation, Dr J van Dorp (who played a pivotal role in this project), was invited for a consultation session with the executive team role in this project), was invited for a consultation session with the executive team
of the project.

20.At this stage, the book teams were grouped into bigger units, for example Pentateuch, Early Prophets, Gospels, et cetera. The activities of each of these Pentateuch, Early Prophets, Gospels, et cetera. The activities of each of these
bigger corpora were coordinated by an exegetical coordinator, who typically was a leading scholar and acted as an exegete for one of the book teams. 
represented by the CBA. When the comments from the readers are received, the comments are considered in light of the translation brief. Where necessary, the translated target text is changed. This document is then finally checked for consistency and proofread by copy editors of the BSSA.

\section{Findings and challenges}

After four years, about $15 \%$ of the work has been completed. ${ }^{21}$ What can be regarded as the most significant findings of this project?

1. Although both determining and/or understanding correctly all the communicative clues of the source text, as well as accurately establishing the cognitive world of the source text's audience is sometimes nearly impossible, striving to make a direct translation was useful in guiding the teams to prepare a source-oriented translation into good Afrikaans.

2. The well-defined, detailed and up-to-date 'translation brief' and lists of agreed-upon translation decisions, that are always and easily accessible to each co-worker, provided the 'objective' yardstick against which many solutions from each of the co-workers and the editorial team could be evaluated. Without such terms of reference, this project would not have been possible.

3. The numerous revisions and recordings of translation decisions were at first perceived as a waste of time. However, it turned out that each revision had a cumulative effect. In other words, literary translation (and translating the Bible is an extremely difficult case) is a complicated and painfully long process. It is a process during which approaching the text as an individual and as teams from various angles simply pays off. What is more, the pay-offs are often much more than one would have expected.

4. A working knowledge of recent insights into the use of particles, word order and many fixed expressions of the source languages that are not always recorded in major grammars and lexica, or discussed in the commentaries, was useful for identifying communicative clues that are typically inadequately represented in most target text translations.

5. An editorial team of experts in the source and target text language, as well as translation studies, who respect and appreciate the insight of one another, is crucial. Needless to say, they must be willing to work long hours for a monetary compensation that does not match their input.

6. This project would not have been possible without the optimal use of available electronic tools (e.g. Paratext and Libronix).

What could be regarded as having been - and in a sense still are - the greatest challenges of this project and its more than 120 co-workers?

1. Communicating the translation brief - in particular the notion 'direct translation' successfully.

21.By the end of October 2011, the following texts were ready to be send to the 'church readers': Genesis 1-25; Leviticus 1-12; Ruth; Esther; Ezra; Joel; Obadiah; Jonah; Micah; Nahum; Zephania; Haggai; Zechariah; Malachi. See also http://www. nuwekerkbybel.co.za/
2. For many co-workers it is difficult to distinguish between the referential and representational meaning of the text.

3. The challenge of the inadequacy of available resources as far as the interpretation of all the communicative clues in the source text is concerned.

4. The number of irresolvable text-critical issues in some of the biblical books.

5. Establishing what was really needed as 'additional' information in the meta-texts.

6. The problem of different levels of competency in the teams.

7. The full schedules of the part-time editorial team.

\section{Acknowledgements}

The financial assistance of the National Research Foundation (NRF) of South Africa towards this research is hereby acknowledged. Opinions expressed in this publication and the conclusions arrived at are those of the authors and are not necessarily to be attributed to the NRF. I also want to thank Prof. B. Combrink, Rev. G. Kritzinger and Prof. E.R. Wendland, for their helpful remarks after reading a draft of this article. One of my postgraduate students, Kris Lyle, made some valuable suggestions to improve the English of this article. However, the mistakes are my responsibility.

\section{Competing interests}

The author declares that he has no financial or personal relationship(s) which may have inappropriately influenced him in writing this article.

\section{References}

Afrikaans, viewed n.d., from http://en.wikipedia.org/wiki/Afrikaans

Berger K. \& Nord, C., 1999, Das neue Testament und frühchristliche Schriften, Übersetzt und kommentiert von Klaus Berger und Christiane Nord, Insel Verlag, Frankfurt am Main.

Bible Society of South Africa. The Committee for the Bible in Afrikaans, 1995-2000, 'Minutes', Bible Society of South Africa, Bellville.

Blakemore, D., 1987, Semantic constraints on relevance, Oxford, Blackwell.

Blakemore, D., 1992, Understanding utterances, Oxford, Blackwell.

Blass, R., 1990, Relevance relations in discourse: With special reference to Sissala, Cambridge University Press, Cambridge. http://dx.doi.org/10.1017/ CBO9780511586293

Carson, D.A., 1993, 'New Bible translations: An assessment and prospect', in H.C. Kee (ed.), The Bible in the twenty-first century, pp. 37-67, American Bible Society, New York.

Centre for Bible Interpretation and Translation in Africa (CEBITA), viewed n.d., from http:// www:cebita.org

Chemorion, D.C., 2008, 'Narrative and poetry genre in the book of Jonah: Towards a participatory approach in Bible translation', DTh dissertation, Department of Ancient Studies, University of Stellenbosch. The Committee for the Bible in Afrikaans, see Bible Society of South Africa.

De Blois, K.F. \& Mewe, T., 2002, 'Functional equivalence and the new Dutch translation project', in J.A. Naudé \& C.H.J. van der Merwe (eds.), Contemporary Translation Studies and Bible translation: A South African perspective, pp. 218-227, Acta Theologica Supplement 2, University of the Free State, Bloemfontein.

De Plooy, H., 2002, 'Listening to the wind in the trees: meaning, interpretation and literary theory', in J.A. Naudé \& C.H.J. van der Merwe (eds.), Contemporary Translation Studies and Bible translation: A South African perspective, pp. 266279, Acta Theologica Supplement 2, University of the Free State, Bloemfontein.

De Vries, L., 2003, 'Paratext and skopos of Bible translation', in W.F. Smelik, A.A. den Hollander \& U.B. Schmidt (eds.), Paratext and megatext as channels of Jewish and Christian traditions, pp. 176-193, Brill, Leiden.

Evans, V. \& Green, M., 2006, Cognitive linguistics: An introduction, Edinburgh University Press, Edinburgh.

Gutt, E-A., 1991, Translation and relevance: Cognition and context, Oxford, Blackwell. Gutt, E-A., 2000, Translation and relevance: Cognition and context, 2nd edn., Jerome Publishers, Manchester. 
Hermanson, E.A., 2002, 'A brief overview of Bible Translation in South Africa', in J.A. Naudé \& C.H.J. van der Merwe (eds.), Contemporary Translation Studies and Bible translation: A South African perspective, pp. 6-18, Acta Theologica Supplement 2, translation: A South African perspective, $\mathrm{pp}$.
University of the Free State, Bloemfontein.

Jordaan, G.J.C., 2002, 'Problems in the theoretical foundation of the functionalequivalent approach', in J.A. Naudé \& C.H.J. Van der Merwe (eds.), Contemporary Translation Studies and Bible translation: A South African perspective, pp. 19-29, Acta Theologica Supplement 2, University of the Free State, Bloemfontein.

Joubert, S.J., 2002, 'No culture shock? Addressing the Achilles heel of modern Bible translations', in J.A. Naudé \& C.H.J. van der Merwe (eds.), Contemporary Translation Studies and Bible translation: A South African perspective, pp. 30-43, Acta Theologica Supplement 2, University of the Free State, Bloemfontein.

Kruger, A., 2002, 'Corpus-based translation research: Its developments and implications for general, literary and Bible translation', in J.A. Naudé \& C.H.J. van der Merwe (eds.), Contemporary Translation Studies and Bible translation: A South African perspective, pp. 70-106, Acta Theologica Supplement 2, University of the Free State, Bloemfontein.

Munday, J., 2001, Introducing Translation Studies: Theories and applications, Routledge, London.

Mojola, A.O., 2002, 'Bible translation in Africa. What implications does the new UBS perspective have for Africa? An overview in the light of the emerging new UBS translation initiative', in J.A. Naudé \& C.H.J. van der Merwe (eds.), Contemporary Translation Studies and Bible translation: A South African perspective, pp. 202213, Acta Theologica Supplement 2, University of the Free State, Bloemfontein.

Naudé, J.A., 2002, 'An overview of recent developments in translation studies with special reference to the implications for Bible translation', in J.A. Naudé \& C.H.J. van der Merwe (eds.), Contemporary Translation Studies and Bible translation: $A$ South African perspective, pp. 44-69, Acta Theologica Supplement 2, University of the Free State, Bloemfontein.

Naudé, J.A. \& Van der Merwe, C.H.J., 2002, Contemporary Translation Studies and Bible translation: A South African perspective, Acta Theologica Supplement 2 Bible translation: A South African perspective
University of the Free State, Bloemfontein.

Nida, E.A. \& Taber, C.R., 1969, The theory and practice of translation, Brill, Leiden.

Nienaber, P.J. \& Heyl, J.A., n.d., Die Afrikaanse Bybelvertaling, Nasou Beperk, Kaapstad.

Nord, C., 1997, Translating as a purposeful activity, St. Jerome Publishing, Manchester.

Nord, C., 2001, 'Loyalty revisited: Bible translation as a case in point', The Translator 7(2), 185-202.

Nord, C., 2002, 'Bridging the cultural gap: Bible translation as a case in point', Acto Theologica 22(1), 98-116.

Ponelis, F., 2002, 'The language ecology of a new Afrikaans Bible', in J.A. Naudé \& C.H.J. van der Merwe (eds.), Contemporary Translation Studies and Bible translation: A South African perspective, pp. 280-289, Acta Theologica Supplement 2, University of the Free State, Bloemfontein.

Pym, A., 2010, Exploring translation theories, Routledge, London.

Smith, K.G., 2001, 'Bible translation and relevance theory: The translation of Titus', DLitt dissertation, Department of Ancient Studies, University of Stellenbosch.

Smith, K.G., 2002, 'Translation as secondary communication. The relevance theory perspective of Ernst-August Gutt', in J.A. Naudé \& C.H.J. van der Merwe (eds.), Contemporary Translation Studies and Bible translation: A South African perspective, pp. 107-117, Acta Theologica Supplement 2, University of the Free State, Bloemfontein.
Snell-Hornby, M., 2006, The turns of Translation Studies: New paradigms or shifting viewpoints?, John Benjamins, Philadelphia.

Sperber, D. \& Wilson, D., 1986, Relevance: Communication and relevance, Blackwell, Oxford.

Van der Merwe, C.H.J., 1993a, 'Old Hebrew particles and the interpretation of the Old Testament text', Journal for the Study of the Old Testament 60, 27-44.

Van der Merwe, C.H.J., 1993b, 'Pragmatics and the translation value of gam', Journal for Semitics 4, 181-199.

Van der Merwe, C.H.J., 1999, "n Konkordante vertaling van die Bybel in Afrikaans: Is dit hoegenaamd verantwoordbaar, en hoe sal dit lyk?', Nederduits Gereformeerde Teologiese Tydskrif 40(3/4), 293-306.

Van der Merwe, C.H.J., 2002, 'An overview of recent developments in the description of Biblical Hebrew relevant to Bible translation', in J.A. Naudé \& C.H.J. van der Merwe (eds.), Contemporary Translation Studies and Bible translation: A South African perspective, pp. 228-245, Acta Theologica Supplement 2, University of the Free State, Bloemfontein.

Van der Merwe, C.H.J. \& Basson, C.S., 2003, "n Nuwe vertaling van die Bybel in Afrikaans: ' $n$ Teoretiese en praktiese oriëntering', Nederduits Gereformeerde Teologiese Tydskrif 44(3/4), 550-567.

Van der Merwe, C.H.J. \& Winckler, W.K., 1993, 'Teaching tomorrow's Bible translators: Some theoretical pointers', Journal of Northwest Semitic Languages 19, 41-59.

Van der Merwe, C.H.J. \& Winckler, W.K., 1994, 'Teaching tomorrow's Bible translators in the light of today's translations', Journal of Northwest Semitic Languages 20, 79-109.

Van der Watt, J.G., 2002, 'What happens when one picks up the Greek text?', in J.A Naudé \& C.H.J. van der Merwe (eds.), Contemporary Translation Studies and Naude \& C.H.J. van der Merwe (eds.), Contemporary Translation Studies and
Bible translation: A South African perspective, pp. 246-265, Acta Theologica Supplement 2, University of the Free State, Bloemfontein.

Van der Watt, J.G. \& Kruger, Y., 2002, 'Some considerations on Bible translation as complex process', in J.A. Naudé \& C.H.J. van der Merwe (eds.), Contemporary Translation Studies and Bible translation: A South African perspective, pp. 118Translation Studies and Bible translation: A South African perspective, pp. 118-
139, Acta Theologica Supplement 2, University of the Free State, Bloemfontein.

Weiss, P.D.F., 1990, Feite en foute oor Bybeltekste en Bybelvertalings, Lux Verbi, Kaapstad.

Wendland, E.R., 1996, 'On the relevance of "Relevance Theory" to Bible translation: A preliminary evaluation', The Bible Translator 47(1), 126-137.

Wendland, E.R., 2002, "Towards a "literary" translation of the Scripture: With special reference to a "poetic" rendition', in J.A. Naudé \& C.H.J. van der Merwe (eds.), Contemporary Translation Studies and Bible translation: A South African perspective, pp. 164-201, Acta Theologica Supplement 2, University of the Free perspective, pp. $164-20$
State, Bloemfontein.

Wendland, E.R., 2011, Email, 18 September, Email unknown.

Wilt, T., 2002a, 'Constructing a contemporary framework for Bible translation', in P.A. Noss (ed.), Current Trends in Scripture Translation 194/195, pp. 11-18, United Bible Society, Brazil.

Wilt, T., 2002b, 'A new framework for Bible translation', in J.A. Naudé \& C.H.J. van der Merwe (eds.), Contemporary Translation Studies and Bible translation: A South African perspective, pp. 140-162, Acta Theologica Supplement 2, University of the Free State, Bloemfontein.

Wilt, T. \& Wendland, E.R., 2008, Scripture frames \& framing, SUN Press, Stellenbosch. 